Article

\title{
Peripherization of Indemnificatory Housing Community under Land-Centered Urban Transformation: The Case of Nanjing, China
}

\author{
Dan Ye ${ }^{1}$, Jingxiang Zhang ${ }^{2}$ and Guoliang $\mathrm{Xu}^{3, *}$ \\ 1 School of Geographic and Oceanographic Sciences, Nanjing University, Nanjing 210023, China; \\ yedan.city@outlook.com \\ 2 School of Architecture and Urban Planning, Nanjing University, Nanjing 210093, China; 3593786@163.com \\ 3 School of Tourism and Urban Management, Jiangxi University of Finance and Economics, \\ Nanchang 330032, China \\ * Correspondence: xuguoliang@jxufe.edu.cn \\ Academic Editor: Tan Yigitcanlar \\ Received: 12 March 2017; Accepted: 17 April 2017; Published: 20 April 2017
}

\begin{abstract}
Indemnificatory housing programs-a kind of state-backed urban low-end and nonmarket housing programs which used to be welfare-have now increasingly evolved to be the vehicle to promote capital accumulation. Most of these housing communities show peripherization with high rates of unemployment, low income, poverty, and social exclusion, which violates their sustainability. This paper examines the impacts of land-centered urban transformation on indemnificatory housing communities, and analyzes the causes of unsustainable outcomes in political economy discourse. To achieve this, the social and economic conditions of a longstanding suburban indemnificatory housing community in Nanjing were analyzed. Survey data collected from March to April 2016 was evaluated to determine the peripherization of the residents within it. We found that for many residents, high rates of unemployment, low income, and poverty were mainly caused by their individual demographic and socioeconomic disadvantages, with the peripheral physical and social location contributing by exacerbating their vulnerabilities. It is concluded that local governments' land-centered urban transformation and the central government's affordable housing policies aimed at social and economic crisis mitigation combine to produce suburban indemnificatory housing communities, driving low-income relocated residents into more disadvantaged situations. This finding creates important lessons for the sustainable development of Chinese indemnificatory housing communities.
\end{abstract}

Keywords: Indemnificatory housing; affordable housing; urban transformation; peripherization; China

\section{Introduction}

Affordable housing has become an increasingly important policy issue in China. Since the mid-to-late 1990s, housing system reform has transferred the responsibility for housing provision from work units to the market, triggering the housing market boom and skyrocketing housing prices. As a result, urban low- and middle-income households and most young migrants cannot afford housing. Polarization within the housing market increasingly intensifies social stratification and instability [1,2]. The central government did not withdraw completely from the housing provision system: it provides various affordable housing programs, such as public rental housing (PRH), with open access for migrants; economically comfortable housing $(\mathrm{ECH})$, houses sold at below-market prices to promote home ownership; shared ownership housing $(\mathrm{SOH})$, under which property is owned between the house-owner and government; etc. [3]. In the early stages, affordable housing 
programs were a kind of post-reform housing welfare for the urban low-income and middle-income households and migrants (especially highly-educated migrants). At present, it is developed for more complicated reasons. On the one hand, with extensive urban renewal and gentrification, a great number of evicted households whose houses are demolished need to be relocated. On the other hand, constrained by affordable housing construction policy issued by the central government to alleviate economic and social crisis to march towards a "harmonious society", local governments are assigned quotas of affordable housing. For example, the central government invested 120 billion RMB on infrastructure in 2008 to mitigate the economic crisis; thereinto, 10 billion RMB was invested in affordable housing construction. Thus, affordable housing is increasingly intended to accommodate relocated households, and should more precisely be called indemnificatory housing. Currently, indemnificatory housing is a kind of state-backed urban low-end and nonmarket housing [4]. For local governments, indemnificatory housing construction is intended more for economic purposes in an era of intense interurban competition than for social justice. Indemnificatory housing programs have become the vehicle to promote urban renewal, through which local governments expropriate valuable lands and relocate residents into suburban low-cost indemnificatory housing communities. Thus, the "indemnificatory housing" to some extent, can be understood as indemnity to those relocated residents.

Lessons from public housing strategies in the U.S. and other countries have emphasized the necessity of avoiding the clustering of public housing in inferior locations $[5,6]$. The popular perception that public housing is notorious for its poverty concentration, racial segregation, high crime rates, and other social pathologies results from inferior allocation [7-9]. The spatial agglomeration of poverty in such areas exacerbates stigmatization and lack of access to employment opportunities [10-12]. Although such allocation patterns have been criticized, the separation of home-work opportunities were still pervasive in the period of rapid urbanization. The public housing boom at the stage of rapid urbanization and industrialization is largely related to urban renewal and slum clearance [13]. This pattern of public housing strategy receives little support from residents due to its decline in public housing provision for the low- and middle-income residents. Despite different concrete forms and manifestations, affordable housing can universally be regarded as the product of urban transformation and economic restructuring in different social contexts [14-16]. Affordable housing problems are often alleviated by changes to the welfare state and increased equality $[13,17,18]$. These problems relate to disparities in income, rising housing costs, irrational urban land-use planning systems, and housing policy [19-22].

During the past two decades in China, most of the affordable housing communities have been located on the urban fringe to save investment costs. According to Song [23], by 2011, 60\% of the affordable housing communities in Beijing were located outside the fifth ring road, and all of the affordable housing communities in Nanjing since 2002 (amounting to 1280 hectare) have been scattered in outer suburbs. This is also the case with Shanghai, Guangzhou, and Wuhan. This affordable housing suburbanization does not couple with the decentralization of low-skill jobs, which would contribute to the poor economic status of the low-income residents by creating spatial mismatch between where they reside and the location of low-skill jobs. This spatial mismatch issue goes in a direction opposite to the western cities, whose jobs-housing mismatch is mainly about the housing discrimination against the racial/ethnic minority groups in the central city and the suburbanization of low-skill jobs [24-27]. However, the Chinese jobs-housing mismatch—like western cities-has resulted in a spatial barrier to the low-income groups. Scholars have also warned that discriminatory site selection of affordable housing and the jobs-housing mismatch in China would bring about the problems of exacerbating poverty, unemployment, and residential and social segregation in the long-term [28-31]. Therefore, in order to ameliorate this unsustainable urbanization, a clear understanding of the phenomenon is required. The existing affordable housing studies in China mainly focus on macro-conditions, the related social and economic policies, especially on housing policy at the national and regional levels during the transformation period. Shi et al. [3] claim that affordable housing policy is an extension 
of economic policy and serves inclusive and equitable urbanization, and thus ensures political consolidation and social stability under new urbanization strategies. Chen [32] elaborates that the PRH in Shanghai is the result of deliberate urban development policy for city marketing and gentrification. In addition to the extensive literature on social stabilization and gentrification, some other researchers argue that the peripheral site selection of affordable housing is the result of local governments' strategic policy to balance top-down pressure with local fiscal interests and the local governments' struggle to complete assigned quotas of affordable housing from the central government [33-36]. Many scholars have stressed the disadvantages of the peripheral spatial agglomeration of affordable housing, which mainly have to do with the insufficient infrastructure and public services $[37,38]$. However, there is a lack of empirical study of the residents' social and economic conditions in affordable housing communities-especially in longstanding indemnificatory housing communities, which could present more deep-rooted problems than newly-built ones. Furthermore, research into land-based interests on affordable housing construction within these communities has rarely been published.

In this paper, the dual track perspective of central-local government interaction is further explored through a case study of a longstanding indemnificatory housing community of Nanjing, in an attempt to understand the peripherization of this type of community. This perspective emphasizes the changes in local governments. This paper argues that land-centered urban transformation is an important factor in the formation of indemnificatory housing communities, and seeks to understand the seriousness of unemployment, low income, poverty, and exclusion problems in China's cities. This paper is organized as follows. Section 2 examines the land-centered urban transformation to understand the formation of indemnificatory housing communities. Section 3 introduces the case of "She Mountain Star Town" (She Shan Xing Cheng, hereafter SMST), a long-standing indemnificatory housing community, and details our research method. Section 4 analyzes the socioeconomic conditions of SMST. Section 5 discusses the findings of the empirical study. The final conclusion is offered to summarize some remarks.

\section{China's Land-Centered Urban Transformation: Towards an Analysis of Indemnificatory Housing Construction}

Explanation of the premise that the central and local governments in China have developed a recent pattern of indemnificatory housing programs begins with understanding the particular ways in which urbanization has developed with its distinct path of capital accumulation.

China has embarked on a series of reforms since 1978 to transform from a highly centralized economy to a market economy, accompanied by an unprecedented pace of urbanization and subsequent increased globalization and neoliberalization. The decentralization reform in the 1990s transferred the development pressure confronting the central state to local governments [39]. Since then, local governments have become self-sustaining entities, and can no longer rely on budgetary allocations from the central government. Post-reform local governments responded to this situation with land-centered urban redevelopment [40], which manifests as urban expansion and renewal. The core of this land-centered urbanization is to capitalize the land for capital accumulation to meet intensified regional and global competition. This is not surprising, because on the one hand, the partial commodification of land allows the conveyance of land use rights; on the other hand, local governments not only maintain political monopolies, but also take control over economic power [41]. Thus, local governments could acquire extensive revenue from land exploitation. In the neoliberal discourse, this land-centered approach has been one of the most significant driving forces of urbanization; namely, urban spatial expansion and renewal have been promoted for spatialized capital accumulation [42].

Under this mode of spatialized capital accumulation, conventional welfare-based affordable housing programs lack incentives for local governments due to their low profits, because local governments would have to give up opportunity costs like land lease fees and various administrative fees to lower the price of affordable housing [33]. Therefore, local governments are prone to take advantage of decentralization in affordable housing programs in a way that minimizes their 
revenue loss. On the one hand, local governments strategically locate affordable housing projects at less-developed urban fringes, where land is much cheaper. On the other hand, affordable housing is built through the demolition of shantytowns, dilapidated neighborhoods, and urban villages in good locations. The low-income residents within these accommodations are evicted to vacate high-value land for gentrification and commercialization. They are forced outwards to suburban areas to be collectively relocated in the newly built indemnificatory housing communities. A number of rural migrants also concentrate in these indemnificatory housing communities after the demolition of the urban villages or shantytowns where they used to live, because private rental housing there is still cheaper than the commodity housing communities. Thus, these residents-almost all laid off, land lost, and low income--belong to the disadvantaged group. Not all residents are poor, but in general they all have limited job opportunities due to the jobs-housing spatial mismatch. As we shall show, the spatial concentration of disadvantaged people as a result of state policy finally leads to the exacerbation of their vulnerable social and economic situations.

\section{Methodology}

\subsection{The Case Study Area}

The indemnificatory housing community examined in this study is SMST in Nanjing. Nanjing is the capital city of Jiangsu province, and one of the major cities in the developed area of the Yangtze River Delta. It has constructed a great amount of indemnificatory housing since the 2000s, and thus provides an ideal case to study indemnificatory housing against the background of dramatic urbanization in China. The rapid growth of indemnificatory housing in Nanjing started in 2003 when it was announced to host the 10th National Games (2005). A series of urban renewal and beautification campaigns were launched to improve Nanjing's urban image. In total, 1.79 million square meters of housing area were demolished, and 24,242 households were evicted in 2003 - both historical firsts (Table 1). Thereafter, affordable housing was built mainly through urban renewal and expansion to accommodate the relocated households. Rapid suburban growth of indemnificatory housing in Nanjing was fuelled by the central government's new strategy in 2010. To ensure residential equity and social justice and to alleviate the economic recession (which is more important), in 2010 the central government proposed to build 36 million units of affordable housing during the 12th Five-Year Plan (2011-2015), and issued a series of policies to transfer this target to local governments to require them to construct affordable housing on a large scale. Since then, the municipal government of Nanjing has built four new affordable housing settlements (Daishan, Shangfang, Huagang, and Dingjiazhuang) and clustered most of the relocated households into these.

Table 1. Amount of demolished housing and supply of public housing in Nanjing (2001-2013).

\begin{tabular}{cccc}
\hline Year & $\begin{array}{c}\text { Demolished Housing } \\
\text { Area (10,000 Units) }\end{array}$ & $\begin{array}{c}\text { Number of } \\
\text { Households Evicted }\end{array}$ & $\begin{array}{c}\text { Constructed Indemnificatory } \\
\text { Housing Area (10,000 Units) }\end{array}$ \\
\hline 2001 & 79.5 & 13,057 & n.a. \\
2002 & 115.4 & 19,104 & 20 \\
2003 & 179 & 24,242 & 91.8 \\
2004 & 83.2 & 15,045 & 159.2 \\
2005 & 48 & 5812 & 122 \\
2006 & 72.3 & 12,460 & 120 \\
2007 & 177.4 & 14,859 & 151.7 \\
2008 & 66.5 & 7748 & 200 \\
2009 & 202 & 22,682 & 256 \\
2010 & 353 & 22,794 & 306 \\
2011 & 313 & 21,419 & 252.9 \\
2012 & 168.5 & 10,173 & 601.5 \\
2013 & 130.2 & 6094 & 557.2 \\
\hline
\end{tabular}

Source: Nanjing Real Estate Yearbook, various years. 
SMST was initially constructed in 2004, mainly to accommodate relocated rural households following the expropriation of their collectively owned land. Its first relocated residents moved in in 2005. It has now also accommodated a few relocated urban households, low- and middle-income urban tenants (there are 1000 units of PRH provided for them), and rural migrants. It is located in suburban Nanjing (Figure 1), far away from the outer ring road, let alone the inner city. SMST was chosen to be the case study area because it has grown very large during the past years (it covers an area of 750,000 square meters, with overall floorage of 1 million square meters, and accommodates more than 20,000 people) and has a high concentration of relocated households, which is typical of most of the newly built indemnificatory housing communities in Nanjing. Moreover, it has gone through a long period of development of various infrastructures and public services, which have been deemed key issues of suburban indemnificatory housing communities and have been increasingly improved. Therefore, this kind of community provides a better case than more newly built ones for exploring deep-rooted problems like unemployment, poverty, and segregation that have not been solved even in the long run, and which are more significant than problems of infrastructure and public service.

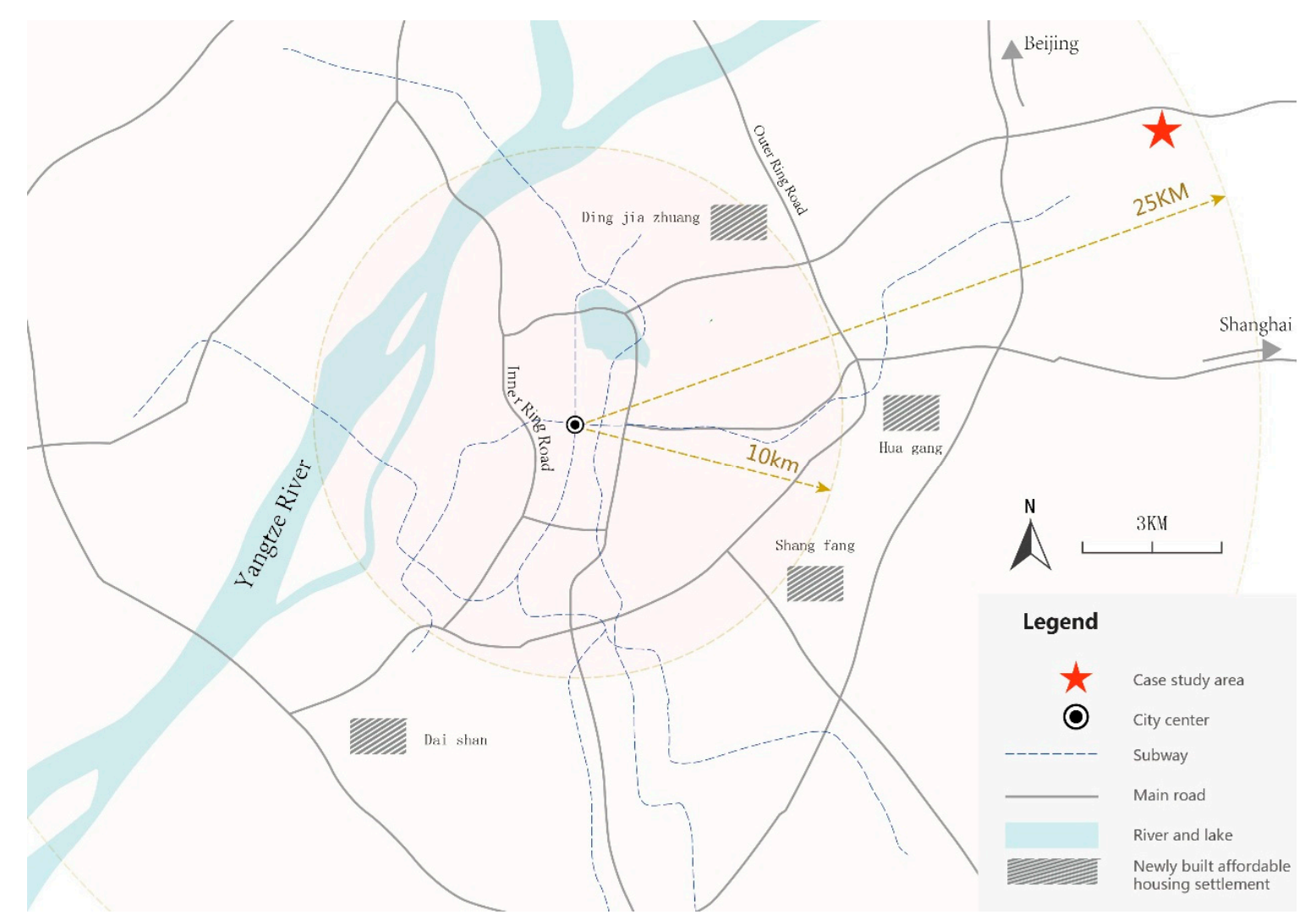

Figure 1. The location of the case study area.

\subsection{Data Collection}

This study mainly focuses on exploring the social and economic characteristics of the residents in SMST. The semi-structured interviews and questionnaire were conducted from March to April 2016 to get a better understanding of the issues facing residents within SMST. The interviews and questionnaire were preceded by fieldwork in February 2016. Semi-structured interviews were conducted with residents, neighborhood committee staff, and the manager of the affordable housing management company. Information received from interviews and official documents in relation to indemnificatory housing and a comprehensive literature review formed the basis for designing the questionnaire. The questionnaire involved details on living status, residential satisfaction, and quality of life of 
the residents in SMST, as well as their satisfaction with their demolition and compensation. Then, the questionnaire survey was carried out based on random sampling. There are three neighborhoods (residents' committee areas) in SMST, and 50 residents were randomly selected according to the address number (with counted intervals based on the sample size and the total addresses) in each neighborhood. One hundred and fifty questionnaires were distributed in the form of face to face, and in total 142 usable questionnaires were returned. Qualitative-driven analysis was employed to analyze the data and materials collected.

Our approach generated relatively concrete and reliable information about a specific type of affordable housing community: indemnificatory housing. Furthermore, our case result can likely represent- to some extent- the situation of indemnificatory housing communities in Nanjing and most other Chinese cities.

\section{Empirical Results}

Based on the data and materials collected, this section will analyze the socioeconomic characteristics of the residents in SMST. Around $68 \%$ of the respondents were heads of the households, $28 \%$ were the partners of heads of households, and $4 \%$ were children or other members of the family. This section mainly concentrates on demographic characteristics, employment, income, poverty, and social exclusion to examine how a longstanding indemnificatory housing community presents its deep-rooted problems.

\subsection{Demographic Characteristics}

In the case study area, there is a large proportion of relocated households, amounting to $86.4 \%$ (Table 2). Of the relocated households, $74.8 \%$ (expressed as a percentage of all respondents) are from demolished urban villages, but were rural residents before relocation. Only $11.6 \%$ of them were urban residents. The length of time these relocated households spent living in SMST ranges from under 1 to 12 years. Among the "long-term housed" (from 6 to more than 10 years), most of them (77\%) were relocated households. The proportion of migrants was much lower, at $10.8 \%$. These numbers reveal that SMST is an indemnificatory housing community which is mainly comprised of owner-occupied housing for accommodating relocated households, as we assumed.

Table 2. Duration of residence by household type.

\begin{tabular}{cccccc}
\hline Household Type & \multicolumn{5}{c}{ Duration of Residence (Year) } \\
\cline { 2 - 6 } & Under One & $\mathbf{1 - 5}$ & $\mathbf{6 - 1 0}$ & More Than Ten & Total \\
\hline $\begin{array}{c}\text { Relocated } \\
\text { household } \\
\begin{array}{c}\text { Migratory } \\
\text { household }\end{array}\end{array}$ & 0.7 & 8.7 & 58.3 & 18.7 & 86.4 \\
$\begin{array}{c}\text { General urban } \\
\text { household }\end{array}$ & 2.9 & 7.9 & 0 & 0 & 10.8 \\
$\quad$ Total & 0 & 0.7 & 2.2 & 0 & 2.9 \\
\hline
\end{tabular}

a Migrants in the sample are neither homeowners nor public housing tenants. They are private housing tenants;

b Property owning urban households who buy their housing from the relocated household.

The proportion of elderly people was relatively high: more than $24 \%$ of the population were older than 60 (China's official standard age of the elderly population is 60 ). In our sample, only $2.8 \%$ of residents were younger than 16, and the labor force population (China's official labor force age is 16-59 for men and 16-54 for women) accounted for about $73 \%$ (Table 3). 
Table 3. The distribution of employment situation by age (expressed as percentages).

\begin{tabular}{cccccc}
\hline \multirow{2}{*}{ Age } & \multicolumn{4}{c}{ Employment Situation } & \multirow{2}{*}{ Total } \\
\cline { 2 - 5 } & Employed & Unemployed & Retired & Other & \\
\hline 16 and under & 0 & 0 & 0 & 2.8 & 2.8 \\
$16-30$ & 15.7 & 1.9 & 0 & 0.9 & 18.5 \\
$31-40$ & 10.2 & 4.6 & 0 & 0.9 & 15.7 \\
$41-50$ & 2.8 & 2.8 & 0 & 2.8 & 8.3 \\
$51-60$ & 7.4 & 7.4 & 13 & 2.8 & 30.6 \\
60 and above & 0.9 & 12 & 10.2 & 0.9 & 24.1 \\
Total & 37 & 28.7 & 23.1 & 11.1 & 100 \\
\hline
\end{tabular}

The educational level of the respondents was rather low compared to the general urban average (Table 4). Only $14.8 \%$ of the respondents had college educations, and no one had postgraduate study experience. About $30 \%$ of the respondents had attained only primary school or had no formal school education at all. The proportion of those with middle school education was $30.6 \%$, which is very low (there is a nine-year compulsory education policy in China, which stipulates that school-age children and teenagers should accomplish a nine-year primary and middle school education).

Table 4. The distribution of employment situation by educational level (expressed as percentages).

\begin{tabular}{cccccc}
\hline \multirow{2}{*}{ Educational Level } & \multicolumn{3}{c}{ Employment Situation } & \multirow{2}{*}{ Total } \\
\cline { 2 - 5 } & Employed & Unemployed & Retired & Other & \\
\hline Elementary school and under & 2.8 & 12 & 13.9 & 1.9 & 30.6 \\
Middle school & 9.3 & 12 & 5.6 & 3.7 & 30.6 \\
High school & 11.1 & 3.7 & 3.7 & 4.6 & 23.1 \\
College and above & 13 & 0.9 & 0 & 0.9 & 14.8 \\
Other & 0.9 & 0 & 0 & 0 & 0.9 \\
Total & 37 & 28.7 & 23.1 & 11.1 & 100 \\
\hline
\end{tabular}

\subsection{Employment, Income, and Poverty}

Unemployment has already become the major problem in SMST. Only about 37\% of residents are employed, and over a quarter of residents are unemployed (Table 4). Because $74.8 \%$ of the sample were rural residents before relocation, as mentioned above, most of them have low levels of education attainment. Therefore, it is not surprising that they are excluded from the urban labor markets for their low competiveness. Table 4 confirms this assertion: a significant proportion of the unemployed people have educational attainment of only elementary school and under or middle school. To sum up, the low educational profile of the residents suggests that they are vulnerable after relocation.

Additionally, age is an important factor contributing to unemployment. Among the unemployed, the "60 and above" age group ranked first, followed by the "51-60" group (Table 3). The residents belonging to these two groups were middle-aged 10 years ago when their lands were expropriated. On the one hand, they were too old to learn new skills to make career transformations, transferring from peasants to employees in the labor market. On the other hand, limited by little savings and demolition compensation, it is difficult for them to start businesses. Although some residents in the 51-60 group are employed, most of them merely have temporary work.

The local neighborhood committee had organized job trainings, but there are few job opportunities in this outer suburban area, which also contributes to the low rate of employment. Only $10.3 \%$ of the employed residents' jobs were arranged by the neighborhood committee. "Job trainings are useless and increasingly become a mere formality. Because we cannot find jobs after training", a relocated resident there complained. In addition, the arranged jobs are always low-skill jobs like security guard, and are so far away from the community (averaging more than three hours commuting time) that the relocated residents have to give them up. 
Because of their poor educational and skill profiles, not many residents could find long-term formal jobs. Of those who are in employment (Table 5), the majority of them are engaged in the informal economy-especially those who were self-employed and work in private enterprises. There are two kinds of informal economy in SMST. One is wage employment in unprotected jobs. This kind of job is always has a low entry cost, but is also temporary and low-paid. Employed residents of this kind are mainly street cleaners, security guards, and doorkeepers, hired by private enterprises with verbal agreements but without any legal contracts. They face the risk of losing their jobs at any time, and almost all of them felt insecure about their positions. The other main informal economy is unregulated self-employed small business or street vending. All of these workers are more or less disadvantaged in the employment system.

Table 5. Employment status of the respondents.

\begin{tabular}{ccc}
\hline Employment Status & Number of Respondents & $\mathbf{\%}$ \\
\hline Private factory & 11 & 19 \\
Private enterprise & 29 & 50 \\
Self-employed & 11 & 19 \\
Public sector & 7 & 12 \\
Total & 58 & 100 \\
\hline
\end{tabular}

In order to identify the relationship between employment and relocation, we cross-analyzed the answers to two questions: (a) whether the respondents have ever changed their jobs after relocation and (b) if yes, the reasons why they changed their jobs. The results reveal that of the $34.5 \%$ who have changed their jobs, about $17.2 \%$ changed due to relocation. However, of the $65.5 \%$ who haven't changed their jobs, more than half of them were mainly engaged in farming before relocation, which means that they have never been employed, whether before or after relocation. The point is that they could depend on farming to make ends meet before relocation, while the situation changed after that. It is difficult for them to find jobs after relocation. Their low level of education attainment and age contribute to high rate of unemployment, while the peripheral physical location with few opportunities exacerbates the problem of unemployment.

In terms of their employment situations, most of the households in the case study area showed a low-income and poor profile. Heads of households and their partners-who accounted for $96 \%$ of the total sample-were the main sources of income. Annual personal incomes of the sample in SMST were compared with the overall average income reported by the municipal statistics bureau (Table 6). A large percentage (57\%) of the sample's average annual income in 2015 was less than RMB 30,000 , which is far less than the city's average of RMB 42,813. The household income per capita was grouped into four types in terms of officially issued standards (Table 7). Table 7 indicates that the vast majority of the households surveyed belong to the low-income group, followed by the minimum living standard (hereafter MLS) group: in total, these two account for $72.2 \%$. There is no wonder that most of the residents there claim that they cannot make ends meet. "We could grow vegetables at that time (before relocation), which helps saving cost a lot, but now everything costs, we do not own jobs. We cannot afford the fresh vegetables in the market, let alone the meat, we buy the inferior leftover vegetables for their lower cost", an unemployed relocated household head said. This perception was echoed by another aged solitary resident: "To save cost, I just eat eggs for three meals, you can find nothing in my refrigerator but eggs."

Low income is accompanied with increased living expenditure. A relocated resident complained that "Everything costs (after relocation), we even have to pay for the property management fees. It is not so good as before (relocation) when we did farming to achieve self-sufficiency, and the living expenditure was very low". This is verified by the questionnaire. More than $38 \%$ of the relocated households (expressed as a percentage of all respondents) put food as their major increase in living expenditure, far exceeding daily necessities $(18.3 \%)$, healthcare/education $(5.6 \%)$, transportation 
$(4.9 \%)$, housing $(4.2 \%)$, and recreation (2.1\%). Spending on food is given much higher priority by people living in this low-income and poor community. Increased recreation expenditure ranks the lowest, which to some extent indicates that most of these relocated households do not purchase the new fashion of urban lifestyle in this low-income area.

Table 6. Distribution of the annual income of the respondents in $2015^{\mathrm{a}}$.

\begin{tabular}{ccc}
\hline Income Group (Yuan) & Number of Respondents & $\%$ \\
\hline 20,000 and less & 70 & 49.3 \\
$20,000-30,000$ & 11 & 7.7 \\
$30,000-50,000$ & 19 & 13.4 \\
$50,000-100,000$ & 17 & 12 \\
100,000 and over & 8 & 5.6 \\
Not responded & 17 & 12 \\
Total & & 100 \\
\hline
\end{tabular}

${ }^{\text {a }}$ Data of the sample calculated from the responses about income last year.

Table 7. Household income per capita of the sample ${ }^{\text {a }}$

\begin{tabular}{ccc}
\hline Group of Household Income Per Capita & The Income Standard (Yuan) $^{\mathbf{b}}$ & $\mathbf{\%}$ \\
\hline Minimum living standard & 700 and less & 31.5 \\
Low income & $701-1921$ & 40.7 \\
Low middle income & $1922-3074$ & 17.6 \\
Middle income and above & 3075 and over & 10.2 \\
Total & & 100
\end{tabular}

a Data of the sample calculated from the responses about income last year; ${ }^{\mathrm{b}}$ The income standards of different income groups were collected from the Nanjing Statistics Bureau.

High rates of unemployment, insecure jobs, and low income are always accompanied by poverty; so is the case in SMST. The problem of poverty is palpable and unsettling. The poverty group is mainly comprised of the unemployed residents (Table 8). The income-based MLS is used to show the poverty level, because MLS is implemented citywide based on the same criteria and varies from city to city. MLS is more reliable than the world poverty standard of US\$1.9 per capita per day (in 2015). The world poverty standard is a rather low measurement used to assess extreme poverty without taking developmental needs into account $[43,44]$. The poverty of indemnificatory housing communities is more the poverty of development than extreme poverty. Minimum living security has existed in Nanjing for years. In March 2016, MLS was set at 700 yuan per person per month in Nanjing. Households with a monthly per capita income below this standard could apply for this subsidy. Table 8 shows that more than 31\% of the households in SMST are suffering from poverty, and should be qualified for this subsidy. However, in reality, only $11.1 \%$ of the them have claimed it. Therefore, SMST is in fact a low-income and poor community.

Table 8. The linkage between poverty and employment situation (expressed as percentages).

\begin{tabular}{cccccc}
\hline \multirow{2}{*}{ Employment Situation } & \multicolumn{3}{c}{ Household Income Per Capita (Yuan) } & \multirow{2}{*}{ Total } \\
\cline { 2 - 5 } & $\mathbf{7 0 0}$ and less & $\mathbf{7 0 1 - 1 9 2 1}$ & $\mathbf{1 9 2 2 - 3 0 7 4}$ & $\mathbf{3 0 9 5}$ and over & \\
\hline Employed & 8.3 & 13.9 & 8.3 & 6.5 & 37 \\
Unemployed & 14.8 & 8.3 & 3.7 & 1.9 & 28.7 \\
Retired & 5.6 & 13.9 & 1.9 & 1.9 & 23.1 \\
Other & 2.8 & 4.6 & 3.7 & 0.0 & 11.1 \\
Total & 31.5 & 40.7 & 17.6 & 10.2 & 100.0 \\
\hline
\end{tabular}




\subsection{Exclusive City: Depression of the Disadvantaged}

There is a relatively high rate of housing satisfaction in SMST. The main positive aspect of housing satisfaction is the preferable housing conditions and the easier access to urban services (reported by $87.1 \%$ of all respondents); for example, the high availability of transportation, hospitals, and schools in SMST (Table 9). However, at the beginning of relocation in 2005, infrastructure and public services there were insufficient. For example, there were no supermarkets or community hospitals, and there was only one bus to the inner city, which made three trips a day. SMST is now within walking distance of supermarkets, schools, and a public health center, and the buses to the inner city were increased to three and make trips every 15 minutes. Furthermore, a subway station is also conveniently located near the community, only three bus stops away. Another major factor contributing to housing satisfaction is continuous local social and kin relationships, because the relocated households were rehoused together with their old neighbors in the same new neighborhoods. Of the respondents, $87 \%$ agreed that they have very good relationships with their neighbors.

Table 9. Distance to various urban services compared to the beginning of relocation (expressed as percentages).

\begin{tabular}{cccccc}
\hline \multirow{2}{*}{ Changes of Distance } & \multicolumn{5}{c}{ Urban Service } \\
\cline { 2 - 6 } & Supermarket & Food Market & Hospital & Primary/Middle School & Bus/Subway Station \\
\hline Increase & 5.2 & 6.3 & 6.4 & 3.6 & 5.5 \\
Decrease & 68.7 & 62.5 & 61.5 & 51.4 & 70.9 \\
No change & 26.1 & 31.2 & 32.1 & 45 & 23.6 \\
Total & 100 & 100 & 100 & 100 & 100 \\
\hline
\end{tabular}

Nevertheless, the high rates of unemployment, low income, and poverty still depress the residents. "This is not what I expected. I don't have a job, and I just stay at home all day", a middle-aged man said. He had stayed at home for a long time. Similar findings were not infrequent in SMST. The unemployed people sit around or play cards all day long in the club that is set up for the aged of the community, even if they are not old. Of the respondents, $15.6 \%$ said that it is hard to maintain livelihoods. The sprawl of depressed emotion and self-abandoned behavior is relevant to the "culture of poverty" [45]. Moreover, although the questionnaire presents a high level of satisfaction about urban services among the respondents, nothing is in good quality compared to that of other commodity housing communities, especially those in the inner city. Better urban services-especially elite schools which are often the most effective way the poor younger generation can change their disadvantaged situation-are provided for the upper and middle classes under marketization. As a result, the residents of this kind of affordable housing community get trapped in an inferior economic and social situation, which can finally evolve to social exclusion. Therefore, their satisfaction is to some extent a kind of subjective cognition due to the differences between urban and rural areas, but not the good quality of the urban services. The imbalance of the distribution of urban services between the indemnificatory housing communities and commodity housing communities do objectively exist under the uneven urban policy and marketization, whether the relocated households feel satisfied with their housing conditions or not.

Their depression disillusions the residents. They start to query the policy of demolition and relocation compensation. Our survey showed that many residents- $72.5 \%$ of the relocated sample-were dissatisfied with their compensation. The major factors shaping residents' dissatisfaction were inequality and injustice during the process of demolition and relocation (including compulsive demolition), unclear demolition procedures, and unreasonable compensation and relocation (Table 10). "We knew nothing about the policies of demolition and compensation at that time, we were informed to remove and be told how much compensation we could get in total. If someone refused to remove, their water and electricity supply would be cut off, and they would even be threatened by losing the compensation", a relocated respondent recalled. The compensation standard is relatively low 
compared to the value of the expropriated land. There is usually not much compensation money left after paying housing costs. Although the compensation standard in Nanjing was raised in 2007 and 2010, the households relocated before that time cannot enjoy the new policies. The relocated households in the SMST petitioned the municipal government for more compensation in 2008. The petition was suppressed, and the young participants were temporarily arrested.

Table 10. Reason for dissatisfaction with demolition and relocation ${ }^{\text {a }}$.

\begin{tabular}{ccc}
\hline Dissatisfaction Reason & Number of Respondents & $\%$ \\
\hline Unreasonable compensation & 72 & 80.9 \\
Unreasonable relocation & 4 & 4.5 \\
Compulsive demolition & 3 & 3.4 \\
Unclear demolition procedure & 6 & 6.7 \\
Other & 4 & 4.5 \\
Total & 89 & 100 \\
\hline
\end{tabular}

\section{Discussion}

Our empirical study of SMST proves that, given a certain period of time, insufficient infrastructures and public services of the suburban indemnificatory housing communities can be developed. However, they are still lower quality compared to other commodity housing communities. Moreover, unemployment, low income, and poverty are more deep-rooted, driving the communities into peripherization.

Three remarkable findings need to be highlighted. Firstly, the peripheral physical location of indemnificatory housing communities results from the land-centered urban transformation. Land-centered urban transformation mainly manifests as urban redevelopment, during which process urban villages, shantytowns, and dilapidated neighborhoods are demolished-a process accompanied by gentrification and commercialization based on the differential rent of urban land. The local residents are excluded and pushed to the periphery. This exclusive location is the result of the unequal rights to the city. It produces an uneven distribution of social resources and development opportunities under marketization, thereby leading to the continuation and exacerbation of unemployment, low income, and poverty, as well as impeding upward mobility and facilitating the "culture of poverty."

Secondly, the problems of unemployment, low income, and poverty are exacerbated by peripheral physical location. The relocated residents-either peasants or urban residents-are essentially the poor and low-income group in the city, with low educational and skill profiles. This means that once evicted and relocated at the urban fringe, few of them have the capability to move. Although housing prices in SMST have increased, along with the improvement of infrastructure and urban services, it does not help a lot because they cannot sell their indemnificatory housing to buy commodity housing in or closer to the inner city. As housing prices in SMST have increased, the price of commodity housing has been skyrocketing, so that SMST residents cannot afford commodity housing with their rather low incomes. Thus, they get trapped in the peripheral physical location for a long time, or even forever. Even worse, on the one hand they cannot maintain their old lifestyles which made it easier to make ends meet through self-sufficiency, especially for the rural relocated residents. On the other hand, there are always few job opportunities around the suburban indemnificatory housing communities, and this severe jobs-housing spatial mismatch decreases the possibility for them to improve their living conditions through employment. As a result, individual demographic and socioeconomic vulnerabilities are exacerbated by peripheral relocation. Many relocated residents are unemployed. The employed mostly get involved in the low-paid and uncertain informal economy. High rates of unemployment and low levels of employment are often accompanied by low income and poverty.

Thirdly, the peripheral physical location of the relocated residents might result in social exclusion. The relocated residents always belong to the low-income disadvantaged group who share a similar 
value system, behavior pattern, and lifestyle, which are different from other groups. The peripheral spatial agglomeration of these people intensifies their heterogeneity, which increasingly pushes them to deviate from the mainstream society, and thus finally results in social exclusion.

\section{Conclusions}

This paper examines the social and economic characteristics of a long standing indemnificatory housing community to explore the impacts of land-centered urban transformation and exclusive urban policies on indemnificatory housing communities in China's cities. Analysis of the case study community shows that indemnificatory housing problems can be viewed as severe problems of unemployment, poverty, and social exclusion. More than a quarter of the residents we studied were unemployed, and most of the employed people were engaged in temporary and low-paid work. A large proportion of the households studied had low incomes, and more than $31 \%$ of the poor households had income below the MLS. There are strong relationships among employment, income, poverty, and personal/household characteristics. Unemployed residents tend to be aged, with low levels of education, and the low-income households tend to be unemployed or temporarily employed. As an original indemnificatory housing community, SMST has evolved into a poor and low-income neighborhood of relocated households. This case study provides a good opportunity to understand the deep-rooted problems of current indemnificatory housing communities. The deep-rooted problems are not the problems of insufficient transportation, hospitals, schools, and other infrastructure or urban services that have been the main focus of and denounced in past studies; rather, they are unemployment, low income, poverty, and social exclusion.

This study finds that the indemnificatory housing community experiences peripherization. However, this peripherization cannot be generalized only as individual or household demographic and socioeconomic attributes of the relocated residents, because affordable housing policy under land-centered urban transformation also contributes to peripherization. In other words, the problem is not only because the relocated residents are not capable of getting secure and formal jobs, or of overcoming poverty because of their low level of educational and skill attainment, but also because the demolition and peripheral physical and social relocation exacerbates their vulnerabilities. In fact, most relocated residents - especially the rural ones-could live secure lives on their lands. However, demolition and peripheral physical and social relocation expropriate their lands and force them into inferior areas without providing enough job opportunities or living security. The jobs-housing mismatch and their intrinsic disadvantages push these low-income disadvantaged people into more disadvantaged situations.

In China, suburban indemnificatory housing communities are developed in response to local governments' affordable housing policies and local governments' land-centered urban transformation. For the central government, affordable housing construction in political economic discourse is a kind of investment in the built environment to solve the problem of excessive capital accumulation in the secondary circuits of capital, according to Harvey [46]. It is also the medium that the central government could depend on to mitigate the social crisis caused by skyrocketing housing prices, to achieve social justice and thus a harmonious society. For local governments, affordable housing is more a vehicle for capital accumulation than for welfare or social justice. On the one hand, in order to balance the top-down pressure and local fiscal revenues, the construction of affordable housing communities is largely related to urban renewal. The original target of urban renewal was to eliminate "informal areas" and to improve residents' living conditions, but current intra-urban residential relocation tends to produce new "informal areas" and leads to new poverty concentration. On the other hand, non-consideration of needs in the process of urban renewal-especially of job opportunities for low-income relocated households-contributes to further peripherization of indemnificatory housing communities. This process reveals that the stress from the central government and local fiscal hardship are converted into a state of deprivation of the disadvantaged.

Thus, besides the land-centered exclusive urban transformation, there is also a need to link the characteristics of the aforementioned indemnificatory housing community to the spatially unequal 
power relations between the disadvantaged group and the powerful group during the process of urbanization. People from the disadvantaged group-especially the low-income relocated households in this study-do not have the power to express themselves. The powerful group—represented by the municipal government-ignores the relocated households' needs, which results in injustice and unequal rights to the city. This situation is obviously unsustainable. With reference to the U.S. and other countries, these indemnificatory housing problems should be alleviated through an integrated consideration of employment, work, real estate, housing policy, and land use planning policy, as well as of justice. Therefore, a more comprehensive and balanced social and economic system is required, and more consideration should be given to the development of pro-relocated residents policies in the indemnificatory housing production. Only in this way can indemnificatory housing communities be sustainable. Envisaging their deep-rooted problems is one step towards getting there.

Author Contributions: Dan Ye organized the field survey, wrote all sections and commented on the manuscript. Jingxiang Zhang revised and constructively commented on the paper. Guoliang $\mathrm{Xu}$ as the correspondence author conceptualized and structure the paper.

Conflicts of Interest: The authors declare no conflict of interest.

\section{References}

1. Lux, M.; Sunega, P.; Katrňák, T. Classes and castles: Impact of social stratification on housing inequality in post-socialist states. Eur. Sociol. Rev. 2013, 29, 274-288. [CrossRef]

2. Wang, H.; Su, F.; Wang, L.; Tao, R. Rural housing consumption and social stratification in transitional China: Evidence from a national survey. Hous. Stud. 2012, 27, 1-18. [CrossRef]

3. Shi, W.; Chen, J.; Wang, H. Affordable housing policy in China: New developments and new challenges. Habitat Int. 2015, 54, 224-233. [CrossRef]

4. Zhang, Z.; Cherry, N.M.; Redmond, D. A crisis of crisis management? Evaluating post-2010 housing restructuring in Nanjing, China. Hous. Policy Debate 2017. [CrossRef]

5. Brown, K.D.; Turner, M.A.; Cunningham, M.; Sawyer, N. Rethinking Local Affordable Housing Strategies: Lessons from 70 Years of Policy and Practice; The Brookings Institution Center on Urban and Metropolitan Policy and the Urban Institute: Washington, DC, USA, 2003.

6. Sinha, A.; Kasdan, A. Inserting community perspective research into public housing policy discourse: The Right to the City Alliance's "We Call These Projects Home". Cities 2013, 35, 327-334. [CrossRef]

7. Carter, W.H.; Schill, M.H.; Wachter, S.M. Polarisation public housing and racial minorities in U.S. cities. Urban Stud. 1998, 35, 1889-1911. [CrossRef]

8. Dekeseredy, W.S.; Schwartz, M.D.; Alvi, S.; Tomaszewski, E.A. Crime victimization, alcohol consumption, and drug use in Canadian public housing. J. Crim. Justice 2003, 31, 383-396. [CrossRef]

9. Goodlad, R. The housing challenge in South Africa. Urban Stud. 1996, 33, 1629-1646. [CrossRef]

10. Flatau, P.; Forbes, M.; Hendershott, P.H.; Wood, G. Homeownership and Unemployment: The Roles of Leverage and Public Housing; NBER Working Papers; National Bureau of Economic Research: Cambridge, MA, USA, 2003.

11. Massey, D.S.; Kanaiaupuni, S.M. Public housing and the concentration of poverty. Soc. Sci. Q. 1993, 74, $109-122$.

12. Wilson, W.J. When Work Disappears: The World of the New Urban Poor; Vintage Books: New York, NY, USA, 1997.

13. Stoloff, J.A. A Brief History of Public Housing; US Department of Housing and Urban Development Office of Policy Development and Research: Washington, DC, USA, 2004.

14. Chen, J.; Stephens, M.; Man, Y. The Future of Public Housing; Springer: Berlin, Germany, 2013.

15. Van Kempen, R.; Van Weesep, J. Gentrification and the urban poor: Urban restructuring and housing policy in Utrecht. Urban Stud. 1994, 31, 1043-1056. [CrossRef]

16. Von Hoffman, A. Why They Built Pruitt-Igoe. In From Tenements to the Taylor Homes; Bauman, J.F., Biles, R., Szylvian, K.M., Eds.; The Pennsylvania State University Press: University Park, PA, USA, 2000; pp. 180-205.

17. Beer, A.; Kearins, B.; Pieters, H. Housing affordability and planning in Australia: The challenge of policy under neo-liberalism. Hous. Stud. 2006, 22, 11-24. [CrossRef]

18. Pichler-Milanovich, N. Urban housing markets in central and Eastern Europe: Convergence, divergence or policy 'Collapse'. Eur. J. Hous. Policy 2001, 1, 145-187. [CrossRef]

19. Bramley, G.; Karley, N.K. How much extra affordable housing is needed in England? Hous. Stud. 2005, 20, 685-715. [CrossRef] 
20. Chiu, R.L.H. Planning, land and affordable housing in Hong Kong. Hous. Stud. 2007, 22, 63-81. [CrossRef]

21. Gurran, N.; Whitehead, C. Planning and affordable housing in Australia and the UK: A comparative perspective. Hous. Stud. 2011, 26, 1193-1214. [CrossRef]

22. Schwartz, A.F. Housing Policy in the United States; Routledge: New York, NY, USA, 2006.

23. Song, W. Social problems incurred from spatial distribution of indemnificatory housing in large cities and governing measures. Urban Dev. Stud. 2011, 18, 103-108.

24. Kain, J. Housing segregation, Negro unemployment and metropolitan segregation. Q. J. Econ. 1968, 82, 175-197. [CrossRef]

25. Mclaffery, S.; Preston, V. Spatial mismatch and employment in a decade of restructuring. Prof. Geogr. 1996, 48, 420-431. [CrossRef]

26. Gobillon, L.; Selod, H.; Zenou, Y. The mechanism of spatial mismatch. Urban Stud. 2007, 44, 2401-2427. [CrossRef]

27. Horner, M. Investigating urban spatial mismatch using job-housing indicators to model home-work separation. Environ. Plan. A 2007, 39, 1420-1440. [CrossRef]

28. Chai, Y.; Yan, Z.; Liu, Z. Spatial differences of home-work separation and the impacts of housing policy and urban sprawl: Evidence from household survey data in Beijing. Acta Geogr. Sin. 2011, 66, 157-166.

29. Fan, Y.; Allen, R.; Sun, T. Spatial mismatch in Beijing, China: Implications of job accessibility for Chinese low-wage workers. Habitat Int. 2014, 44, 202-210. [CrossRef]

30. Zhou, S.; Wu, Z.; Cheng, L. The impact of spatial mismatch on residents in low-income housing neighbourhoods: A study of the Guangzhou Metropolis, China. Urban Stud. 2013, 50, 1817-1835. [CrossRef]

31. Xu, Y.; Chan, E.; Yung, E. Analysis of the mechanisms contributing to spatial mismatch in transitional Chinese cities. J. Urban Plan. Dev. 2014, 140, 1-7. [CrossRef]

32. Chen, J. The development of new public rental housing in Shanghai. Crit. Hous. Anal. 2014, 1, 26-34. [CrossRef]

33. Dang, Y.; Liu, Z.; Zhang, W. Land-based interests and the spatial distribution of affordable housing development: The case of Beijing, China. Habitat Int. 2014, 44, 137-145. [CrossRef]

34. Huang, Y. Low-income housing in Chinese cities: Policies and practices. China Q. 2012, 212, 941-964. [CrossRef]

35. Wang, Y.P.; Murie, A. The new affordable and social housing provision system in China: Implications for comparative housing studies. Eur. J. Hous. Policy 2011, 11, 237-254. [CrossRef]

36. Zou, Y. Contradictions in China's affordable housing policy: Goals vs. structure. Habitat Int. 2014, 41, 8-16. [CrossRef]

37. Cheng, M.; Zhang, W.; Lu, D. Examining spatial pattern and location choice of affordable housing in Beijing, China: Developing a workable assessment framework. Urban Stud. 2015, 52, 1846-1863. [CrossRef]

38. Zhang, T.; Hashim, A.H.B. Theoretical framework of fair distribution of affordable housing in China. Asian J. Soc. Sci. 2011, 7, 175-183. [CrossRef]

39. Wu, F. China's changing urban governance in the transition towards a more market-oriented economy. Urban Stud. 2002, 39, 1071-1093. [CrossRef]

40. Lin, G.C.S. Reproducing spaces of Chinese urbanisation: New city-based and land-centred urban transformation. Urban Stud. 2007, 44, 1827-1855. [CrossRef]

41. Nonini, D.M. Is China becoming neoliberal? Crit. Anthr. 2008, 28, 145-176. [CrossRef]

42. He, S.; Wu, F. China's emerging neoliberal urbanism: Perspectives from urban redevelopment. Antipode 2009, 41, 282-304. [CrossRef]

43. He, S.; Liu, Y.; Wu, F.; Webster, C. Poverty incidence and concentration in different social groups in urban China, a case study of Nanjing. Cities 2008, 25, 121-132. [CrossRef]

44. Wu, F. The poverty of transition: From industrial district to poor neighbourhood in the city of Nanjing, China. Urban Stud. 2007, 44, 2673-2694.

45. Beall, J. From the culture of poverty to inclusive cities: Re-framing urban policy and politics. J. Int. Dev. 2000, 12, 843-856. [CrossRef]

46. Harvey, D. The Urbanization of Capital: Studies in the History and Theory of Capitalist Urbanization; The Hopkins University Press: Baltimore, MD, USA, 1985.

(C) 2017 by the authors. Licensee MDPI, Basel, Switzerland. This article is an open access article distributed under the terms and conditions of the Creative Commons Attribution (CC BY) license (http:/ / creativecommons.org/licenses/by/4.0/). 